\title{
The relationship between subsurface hydrology and dissolved carbon fluxes for a sub-arctic catchment
}

\author{
S. W. Lyon ${ }^{1}$, M. Mörth ${ }^{2}$, C. Humborg ${ }^{3}$, R. Giesler ${ }^{4}$, and G. Destouni ${ }^{1}$ \\ ${ }^{1}$ Physical Geography and Quaternary Geology, Stockholm University, Sweden \\ ${ }^{2}$ Geology and Geochemistry, Stockholm University, Sweden \\ ${ }^{3}$ Applied Environmental Science, Stockholm University, Sweden \\ ${ }^{4}$ Climate Impacts Research Centre, Department of Ecology and Environmental Science, Umeå University, Sweden
}

Received: 10 February 2010 - Published in Hydrol. Earth Syst. Sci. Discuss.: 3 March 2010

Revised: 6 May 2010 - Accepted: 1 June 2010 - Published: 15 June 2010

\begin{abstract}
In recent years, there has been increased interest in carbon cycling in natural systems due to its role in a changing climate. Northern latitude systems are especially important as they may serve as a potentially large source or sink of terrestrial carbon. There are, however, a limited number of investigations reporting on actual flux rates of carbon moving from the subsurface landscape to surface water systems in northern latitudes. In this study, we determined dissolved organic carbon (DOC) and dissolved inorganic carbon (DIC) fluxes from the subsurface landscape for a sub-arctic catchment located in northern Sweden. These are based on observed annual flux-averaged concentrations of DOC and DIC for the $566 \mathrm{~km}^{2}$ Abiskojokken catchment. We demonstrate the importance to correctly represent the spatial distribution of the advective solute travel times along the various flow and transport pathways. The fluxes of DOC and DIC from the subsurface landscape to the surface water system were comparable in magnitude. This balance could shift under future climatic changes that influence the hydrological and biogeochemical system.
\end{abstract}

\section{Introduction}

There may be numerous climate change effects on hydrology at high-northern latitudes. These include decreasing depth and duration of snowcover (Brown and Braaten, 1998; Curtis et al., 1998), permafrost warming and thawing (Stieglitz et al., 2003; Walvoord and Striegl, 2007; Osterkamp, 2007), increasing precipitation frequency and amount (Walsh, 2000;

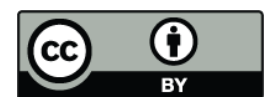

Correspondence to: S. W. Lyon

(steve.lyon@natgeo.su.se)
McCabe et al., 2001), increasing freshwater discharge (Peterson et al., 2002) and earlier spring flood peak discharges (Déry et al., 2005). The terrestrial freshwater cycle in the arctic and sub-arctic is often intimately connected with the presence of permafrost (White et al., 2007; Woo et al., 2008) and the depth to the permafrost largely determines the pathways of water flow through the landscape (Kane et al., 1981). In addition to influencing the hydrological response of the landscape, the location and distribution of these pathways influence the carbon and other biogeochemical cycling in northern latitude catchments (e.g., MacLean et al., 1999; McNamara et al., 2008).

Increasing precipitation and surface temperature may lead to more subsurface water flowing through the highly organic superficial soils of arctic and sub-arctic systems, promoting the transport of dissolved organic carbon (DOC) from the subsurface landscape to the surface water system (Dutta et al., 2006); in addition, permafrost degradation may result in DOC release (Frey and McClelland, 2009). Permafrost thawing could also allow for deeper flow pathways and, as such, lead to a general reduction in terrestrial DOC export by promoting flow through deeper mineral soils (Striegl et al., 2007). Deeper groundwater flow depths would also likely increase dissolved inorganic carbon (DIC) formation due to weathering. Such shifts in DOC and DIC transport and/or production would have consequences for the global $\mathrm{C}$ balance. Increased DOC concentrations could enhance respiration rates in the surface water system (e.g., Sobek et al., 2003), which would impose a positive feedback on atmospheric $\mathrm{CO}_{2}$. Increases in silicate weathering and DIC production, however, consumes $\mathrm{CO}_{2}$ and would constitute a negative feedback on atmospheric $\mathrm{CO}_{2}$ (Smedberg et al., 2006).

Published by Copernicus Publications on behalf of the European Geosciences Union. 

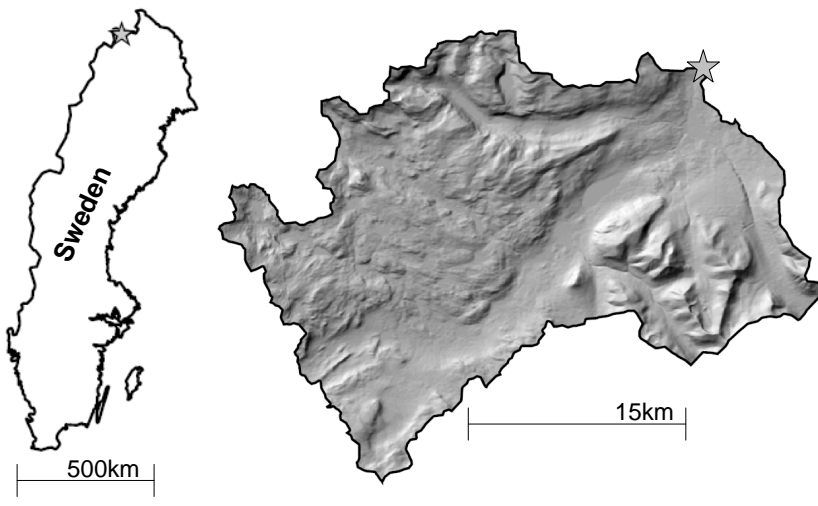

Fig. 1. Site map showing the Abiskojokken catchment in northern Sweden with the outlet (indicated by a star) at $68^{\circ} 21^{\prime} 36^{\prime \prime} \mathrm{N}$, $18^{\circ} 46^{\prime} 48^{\prime \prime} \mathrm{E}$.

The net effect of these opposing feedback mechanisms depends on the rates of respiration and weathering relative to the DOC and DIC mass transport rates along the different pathways of subsurface water flow. In order to predict the fates of solutes, the transport time of water and solutes along the diverse flow pathways through a catchment must be quantified (Destouni and Graham, 1995; Simic and Destouni, 1999; Kirchner et al., 2001; Malmström et al., 2004; Darracq et al., 2009; Persson and Destouni, 2009). Field-based identification of flow pathways and quantification of the travel time of water along such flow pathways, however, is difficult both in terms of collection of appropriate data and in terms of interpretation. As hydrological mass transport remains poorly investigated at northern latitudes (Hannerz and Destouni, 2006; Bring and Destouni, 2009), an empirical identification of the main solute sources and transport pathways is difficult (Destouni et al., 2008a, b). One option is to estimate the distributions of solute travel times along different flow and transport pathways through catchments using physically-based modeling approaches (e.g., Darracq et al., 2009).

In this study, we simulated solute travel times based on long-term data from the sub-arctic Swedish Abiskojokken catchment. Our objective was to determine water flow and mass transport effects on the present-day release rates of dissolved carbon from the subsurface landscape to the surface water system.

\section{Materials and methods}

\subsection{Site description}

We conducted our study in the sub-arctic $566 \mathrm{~km}^{2}$ Abiskojokken catchment (Fig. 1) in northern Sweden $\left(68^{\circ} 21^{\prime} 36^{\prime \prime} \mathrm{N}\right.$, $18^{\circ} 46^{\prime} 48^{\prime \prime} \mathrm{E}$ ) which ranges in elevation from about $350 \mathrm{~m}$ to $1600 \mathrm{~m}$ above sea level. Precipitation observed in the region ranges from higher values around $\sim 900 \mathrm{~mm} / \mathrm{yr}$ near the Nor- wegian border to lower values around $\sim 300 \mathrm{~mm} / \mathrm{yr}$ near the outlet of the Abiskojokken catchment ( $\AA$ kerman and Johansson, 2008). The mean annual air temperature for 1913-2006 at Abisko (located a few kilometers east of the catchment outlet) was $-0.6{ }^{\circ} \mathrm{C}$ (Abisko Scientific Research Station). The catchment contains both alpine and subalpine vegetation zones. The alpine region is dominated by heath vegetation mainly as dwarf shrubs and the subalpine zone by birch forest with patches of dwarf shrubs. Wetlands and marshes can also be found in the subalpine zone and at lower altitudes in the alpine zone. The Abiskojokken catchment is in an area of discontinuous permafrost (Johansson et al., 2006) with a patchy distribution of permafrost.

Soils at higher altitudes in the alpine zone are shallow with common occurrences of exposed bedrock while soils in the low- and mid-alpine zone are generally deeper. The average soil depth in the adjacent headwaters of the river Kalixälven with a similar elevation range has been estimated to be about 1.7 to $5.3 \mathrm{~m}$ (Smedberg et al., 2006). Regionally, Smedberg et al. (2009) report median soil depth values ranging from around $9 \mathrm{~m}$ for mixed forest land cover to around $7 \mathrm{~m}$ for herbaceous land cover. While a formal soil classification is not available, the till soils typical of this region are sandy (e.g., Johansson et al., 2005) and exhibit effective porosity and hydraulic conductivity values of $0.05 \mathrm{~cm}^{3} / \mathrm{cm}^{3}$ and $1.5 \times 10^{-5} \mathrm{~m} / \mathrm{s}$, respectively, for the quaternary deposits/bedrock interface. The tills in the lower elevations and valleys of Abiskojokken catchment and nearby regions consist largely of finer material, fluvial gravels, sand and in some cases silty/clayey material (Åkerman and Malmström, 1986).

\subsection{Long-term observations and stream water sampling}

Stream water alkalinity at the outlet of Abiskojokken was determined monthly from 1978 through 2008. These (and other chemical measures) are available through the Swedish University of Agricultural Sciences (SLU) Department of Environmental Assessment monitoring program. The annual water flow volume averaged $4.5 \times 10^{8} \mathrm{~m}^{3}$ (1918-2007; Lyon et al., 2009). Daily stream flows are available through the Swedish Meteorological and Hydrological Institute (SMHI) (Gage ID 957). During mid-April to mid-July and September to October 2008, stream samples were manually collected each week at the outlet of the Abiskojokken catchment. DOC concentrations were analyzed for the first sampling campaign $(n=22)$. DOC concentration was analyzed by means of catalytic carbon combustion (Shimadzu TOC-V CPH; Kyoto, Japan). DIC concentrations were calculated for both sampling campaigns $(n=30)$. DIC was calculated from measured alkalinity and pH using PHREEQCI (Parkhurst and Appelo, 1999). PHREEQCI is a graphical user interface version of the PHREEQC computer program used for speciation, batchreaction, one-dimensional transport, and inverse geochemical calculations. 


\subsection{Shallow and deeper flow domain partitioning}

A first step to determining a present-day advective transport travel time distribution for the Abiskojokken catchment is to determine the portioning of flow through shallow and deeper flow domains. To do this, we develop a simple twocomponent hydrograph separation (Sklash and Farvolden, 1979; Buttle and McDonnell, 2004) using long-term monthly samplings of stream water alkalinity. As alkalinity is added to surface water via the deeper pathways in this system (Humborg et al., 2004), we can use the monthly average alkalinity values to separate the observed total streamflow into water coming from the deeper versus shallow flow domain. This assumes that stream flow is primarily derived from the deeper flow domain during winter since the shallow flow domain freezes, and that alkalinity levels thus provide a tracer of water from the deep flow domain. This hydrograph separation, thus, uses the total average annual volumetric stream flow $Q\left[\mathrm{~L}^{3} \mathrm{~T}^{-1}\right]$ to define the average annual flow volume coming from the shallow flow domain $Q_{\mathrm{sh}}\left[\mathrm{L}^{3} \mathrm{~T}^{-1}\right]$ and the deeper flow domain $Q_{\mathrm{d}}\left[\mathrm{L}^{3} \mathrm{~T}^{-1}\right]$.

In addition, we can use this hydrograph separation to check the validity of the hydraulic properties for the shallow and deeper flow domains. This is done by estimating the relative average aquifer thicknesses for both the shallow $Z_{\mathrm{sh}}$ $[\mathrm{L}]$ and the deeper $Z_{\mathrm{d}}[\mathrm{L}]$ flow domains as:

$Z_{\mathrm{sh}}=\frac{Q_{\mathrm{sh}}}{\overline{q_{\mathrm{sh}}} L_{\mathrm{s}}}$

$Z_{\mathrm{d}}=\frac{Q_{\mathrm{d}}}{\overline{q_{\mathrm{d}}} L_{\mathrm{s}}}$

where $L_{\mathrm{s}}[\mathrm{L}]$ is the stream length draining the catchment (approximately $520 \mathrm{~km}$ for the Abiskojokken catchment based on map analysis), and $\overline{q_{\mathrm{sh}}}\left[\mathrm{L} \mathrm{T}^{-1}\right]$ and $\overline{q_{\mathrm{d}}}\left[\mathrm{L} \mathrm{T}^{-1}\right]$ are the average specific discharges from the shallow and deeper flow domains, respectively. By modeling the present-day advective solute transport travel time distribution (see following section), it is possible to estimate $\overline{q_{\mathrm{sh}}}$ and $\overline{q_{\mathrm{d}}}$ values that are dependent on the assumed hydraulic properties of the shallow and deeper flow domains. Substituting into Eqs. (1) and (2), it is possible to calculate the average aquifer thicknesses ( $Z_{\mathrm{sh}}$ and $Z_{\mathrm{d}}$, respectively) for the Abiskojokken catchment. These values can be compared to aquifer thickness observations as a check on the validity of the adopted hydraulic properties used to estimate the advective solute travel times.

\subsection{Advective solute travel times}

The advective travel times of dissolved carbon along subsurface transport pathways to the stream network reflect the purely physical rates of advection by the variable mean pore water velocity along and among these pathways (see the travel time-based modeling approaches of both conservative and reactive solute transport in Destouni and Graham, 1995;
Eriksson and Destouni, 1997; Simic and Destouni, 1999; Malmström et al., 2004; Lindgren and Destouni, 2004; Lindgren et al., 2004; Darracq et al., 2009; and Persson and Destouni, 2009).

We conceptualize the whole subsurface flow domain of active carbon release as a shallow and deeper flow domain. The physical fractionation of water between these two domains is quantified using the above mentioned hydrograph separation. It is possible to define a fraction of streamlines $\left(\alpha_{\mathrm{sh}}\right.$ $[-])$ through the shallow flow domain with advective solute travel times $\tau_{\mathrm{sh}}$ [T]. Complimentary to this, there is a fraction of streamlines $\left(1-\alpha_{\mathrm{sh}}\right)$ through the deeper flow domain with advective travel times $\tau_{\mathrm{d}}[\mathrm{T}]$. Combining these, a flowweighted mean advective travel time $\tau[\mathrm{T}]$ from each point at the surface of the catchment through the whole subsurface flow domain can then be estimated as:

$\tau=\alpha_{\mathrm{sh}} \tau_{\mathrm{sh}}+\left(1-\alpha_{\mathrm{sh}}\right) \tau_{\mathrm{d}}$

We evaluate these advective solute travel times by a simple Darcy-flow quantification. For the shallow flow domain this is (see e.g. also Darracq et al., 2009):

$\tau_{\mathrm{sh}}=\int_{\underline{a}}^{x_{\mathrm{cp}}} \frac{d X_{\mathrm{sh}}}{v\left(X_{\mathrm{sh}}\right)} \approx \int_{\underline{a}}^{x_{\mathrm{cp}}} \frac{d X_{\mathrm{sh}}}{\left(\frac{k_{\mathrm{sh}}}{n_{\mathrm{sh}}} \frac{d h}{d l}\right)_{X_{\mathrm{sh}}}}$

where $x$ defines direction in a moving coordinate system that follows the mean water flow direction. $X_{\mathrm{sh}}(t)$ gives the position along $x$ at time $t$ of a water and solute parcel (e.g., dissolved carbon) traveling from an input location $\underline{a}$ (vector notation) to an output control plane at $x_{\mathrm{cp}}$. At each position $X_{\mathrm{sh}}$, the local average pore water velocity $v\left(X_{\mathrm{sh}}\right)\left[\mathrm{L} \mathrm{T}^{-1}\right]$ advects the water and solute parcel forward in the $\mathrm{x}$-direction. This local average pore water velocity can be defined in a Darcy sense using the local effective water content/porosity $n_{\mathrm{sh}}[-]$, the saturated hydraulic conductivity $k_{\mathrm{sh}}\left[\mathrm{L} \mathrm{T}^{-1}\right]$ and the hydraulic gradient $d h / d l[-]$ in the direction $\mathrm{x}$. The advective travel time is the total time period it takes for the watersolute parcel to be advected from input $\underline{a}$ to output $x_{\mathrm{cp}}$ which here represent the catchment surface and the interface between the subsurface system and the nearest stream or other surface water, respectively. The advective travel time through the deeper flow domain can be calculated in a similar manner (i.e., swapping the subscript "sh" for $d$ in Eq. 4).

Similar to Jarsjö et al. (2007), we use here a geographical information system (GIS) to estimate the flow pathway lengths and hydraulic gradients directly from the available digital elevation model (DEM), which has a resolution of $50 \times 50 \mathrm{~m}$ for the entire catchment. We used the D8 flow routing algorithm as implemented in Tarboton (1997) to define flow pathways and lengths for each non-stream network raster cell in the catchment to the stream network. At each $50 \times 50 \mathrm{~m}$ grid cell along each flow pathway, the upslope contributing area was calculated and used to create a map showing the accumulated area draining to each point in the catchment. On such a map, the highest values (i.e., the positions in 

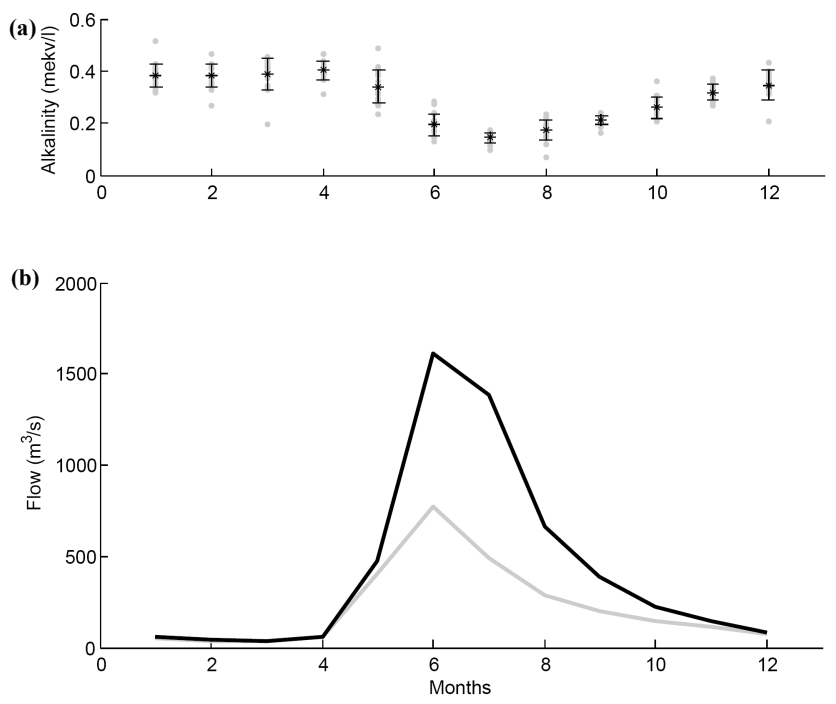

Fig. 2. (a) Long-term (22 years) observations of monthly alkalinity concentrations (grey dots) at the outlet of the Abiskojokken catchment and (b) the resultant hydrograph separation between shallow (area between black and grey lines) and deep (area below the grey line) ground water. In (a), crosses show the mean in a given month and vertical bars show one standard deviation. In (b), uncertainty bounds are not shown as this estimate is intended to give a firstorder approximation of the partitioning of flow between the shallow and deeper domains.

the landscape with the most accumulated area) typically correspond to stream network and can, thus, be used to define the extent of the stream network. This is done by thresholding the map of accumulated area at a critical value such that positions with higher accumulated areas than that critical value are considered part of the stream network. The stream network was defined using a critical accumulated area threshold set at $5 \mathrm{~km}^{2}$. As the groundwater level and slope may be relatively unaffected by small-scale variations in surface elevation (Darracq et al., 2009), the hydraulic gradient was assumed to be equivalent to a hillslope average gradient derived from the DEM. Hillslopes were delineated using the stream network using the methodology described in Bogaart and Troch (2006).

To characterize the hydraulic parameters associated with the shallow flow domain, we adopt reported effective porosity and hydraulic conductivity values for the surface till soils in this catchment. For the deeper flow domain, we assume (as a first-order approximation) hydraulic properties are similar to those for the shallow flow domain. We can check the validity of these assumed hydraulic properties independently (and if found necessary adjust) by estimating the depth of the shallow and deeper flow domains from Eq. (1) and Eq. (2), respectively.

\subsection{Carbon flux estimates}

The release of dissolved carbon into the subsurface water flow pathways can be estimated using the aforementioned advective solute travel times. For example, the DOC release from the subsurface occurs at a rate $r_{\text {DOC }}$ (mass per bulk soil volume $\left[\mathrm{ML}^{-3}\right]$ ) over the whole subsurface flow domain, i.e., over the shallow and the deep flow domains. Following a single flow and transport pathway (stream tube) with mean specific discharge $q\left[\mathrm{~L} \mathrm{~T}^{-1}\right]$ and porosity $n[-]$ along its whole length $L$ it is possible to estimate the local mass flux of DOC, $s_{\mathrm{DOC}}\left[\mathrm{ML}^{-2} \mathrm{~T}^{-1}\right]$, into the nearest surface water as:

$s_{\mathrm{DOC}}=r_{\mathrm{DOC}} L=r_{\mathrm{DOC}} q \tau / n=r_{\mathrm{DOC}} u \tau$,

where $u=q / n$ is the mean pore water velocity $\left[\mathrm{L} \mathrm{T}^{-1}\right]$ along the whole stream tube with mean travel time $\tau$ [T]. Extending this to the whole $\tau$ population of stream tubes that receive DOC and transport it to the receiving surface water, the average mass flux $\overline{s_{\mathrm{DOC}}}\left[\mathrm{ML}^{-2} \mathrm{~T}^{-1}\right]$ into the stream network can be expressed as:

$\overline{s_{\mathrm{DOC}}}=\int_{0}^{\infty} r_{\mathrm{DOC}} u(\tau) \tau f(\tau) d \tau$

where $f$ is the probability density function describing the spatial distribution of solute travel times $\tau$ through the whole subsurface flow domain. This average mass flux can further be related to the flux-averaged concentration of DOC $\overline{C_{\mathrm{DOC}-\text { flux }}}\left[\mathrm{ML}^{-3}\right]$ in the total volumetric stream flow $Q$ $\left[\mathrm{L}^{3} \mathrm{~T}^{-1}\right]$ through the stream cross-sectional area $A_{\mathrm{s}}\left[\mathrm{L}^{2}\right]$ at its outlet as:

$\overline{C_{\text {DOC-flux }}}=\overline{s_{\mathrm{DOC}}} /\left(Q / A_{\mathrm{s}}\right)$

Similarly to the above, the release of DIC into the subsurface water occurs at the rate $r_{\text {DIC }}$ (mass per bulk soil volume). With analogous equations to the result above, we can express the local mass flux $\left(s_{\mathrm{DIC}}\right)$, the average mass flux $\left(\overline{\mathrm{SIC}_{\mathrm{DI}}}\right)$, and the flux-averaged concentration $\left(\overline{C_{\text {DOC-flux }}}\right)$ of DIC.

Using the above expressions, it is possible to link the observed flux-averaged concentrations of DOC and DIC to their associated average mass flux from the subsurface system and the corresponding release rates using spatial distributions of advective solute travel times. To demonstrate the effect of the spatial variability in the advective solute travel time distribution, we use a catchment-average travel times $(\bar{\tau})$ to estimate homogeneous release rates $r_{\mathrm{DOC}}(\bar{\tau})$ and $r_{\mathrm{DIC}}(\bar{\tau})$. Additionally, considering the catchment-average flow velocity we can estimate the homogeneous mass fluxes $\overline{s_{\mathrm{DOC}}}(\bar{\tau})$ and $\overline{s_{\mathrm{DIC}}}(\bar{\tau})$.

\section{Results}

\subsection{Hydrograph separation}

Based on the separation (Fig. 2), $52 \% \pm 4 \%$ (based on one standard deviation in monthly alkalinity samples) of the 


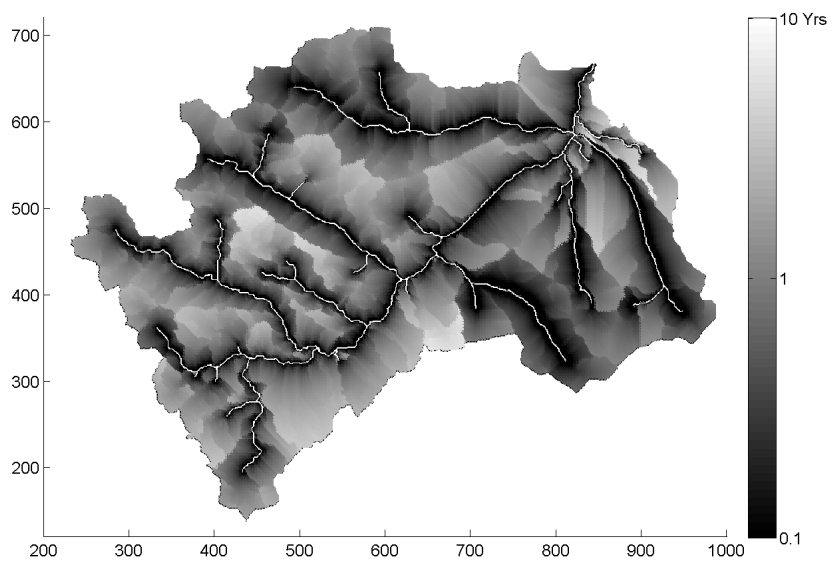

Fig. 3. Present day spatially distributed travel times for each point in the Abiskojokken catchment through the subsurface landscape to the stream network. Note that the color bar has a log scale to show the variability in the spatial distribution. The axes for the map of spatially distributed travel times are labeled in kilometers of linear distance.

average annual flow from the Abiskojokken catchment originates from the deeper flow domain. It follows that the remaining $48 \% \pm 4 \%$ is derived from the shallow flow domain. This gives a long-term estimate of $\alpha_{\mathrm{sh}} \approx 0.48$ for the Abiskojokken catchment. Based on the total long-term average annual flow for Abiskojokken, this yields $Q_{\mathrm{sh}} \approx 2.16 \times 10^{8} \mathrm{~m}^{3}$ per year and $Q_{\mathrm{d}} \approx 2.34 \times 10^{8} \mathrm{~m}^{3}$ per year as the flow contribution from the shallow and the deeper flow domain to the stream network, respectively.

\subsection{Advective solute travel times}

The estimation of $\tau$ (Fig. 3) is sensitive to the $\alpha_{\text {sh }}$ value, as this parameter controls the fractionation of flow pathways between the shallow and the deeper flow domains and to the hydraulic properties adopted to represent each of the zones. Substituting into Eqs. (1) and (2), we estimate an aquifer thickness of about $4 \mathrm{~m}$ for the deeper flow domain and $4 \mathrm{~m}$ for the shallow flow domain, yielding depth for the whole subsurface flow domain of $8 \mathrm{~m}$.

Characteristic distributions show that the present-day travel time distribution is highly skewed towards smaller travel times and exhibits a long tail of large travel times (Fig. 4). The mean advective travel time from the statistical distribution is then 0.9 years, the median travel time is 0.6 years, and the standard deviation is 0.8 years.

\subsection{DOC and DIC observations and flux estimates}

The time series of DOC and DIC concentrations show seasonal trends (Fig. 5). Typically, the observed DIC concentrations are larger than the observed DOC concentrations. DOC concentrations are small prior to spring thaw, show a peak at $3.9 \mathrm{mg} / \mathrm{L}$ immediately following spring thaw and decline to- (a)

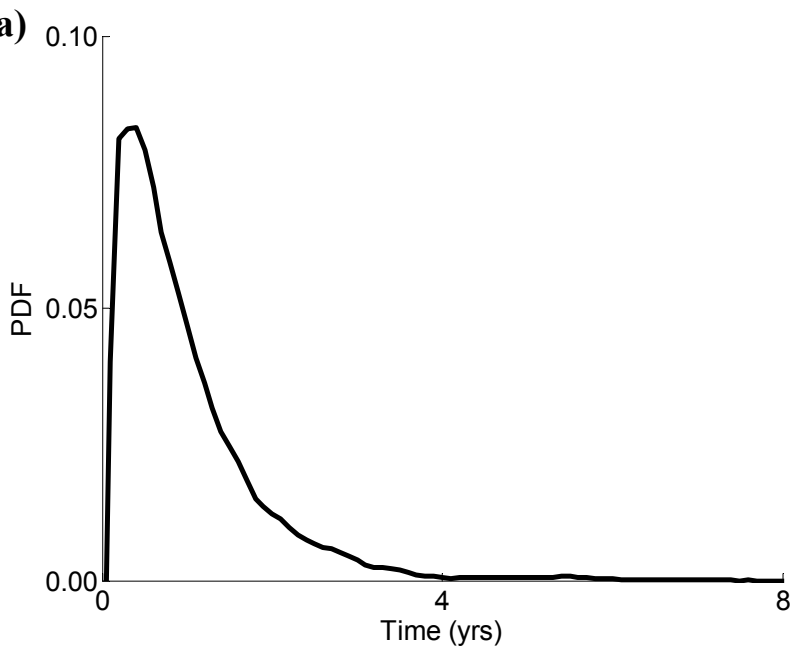

(b)

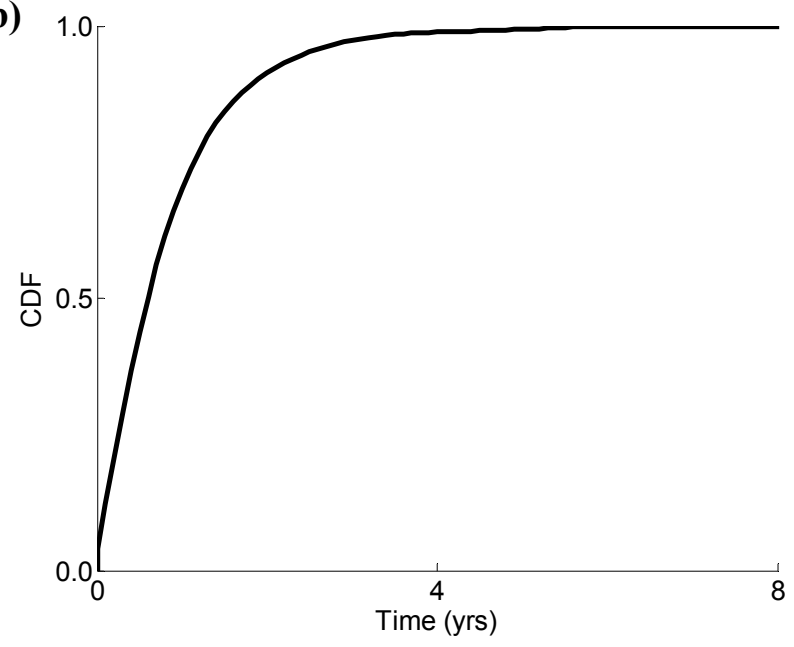

Fig. 4. Characteristic distributions summarizing (a) probability density function (PDF) and (b) the cumulative distribution function (CDF) of the spatially distributed travel times given in Fig. 3.

wards late summer. DIC concentrations drop markedly during the spring thaw and reach a minimum at $1.8 \mathrm{mg} / \mathrm{L}$ during the summer. This DIC concentration pattern in 2008 corresponds to the long-term average pattern seen for alkalinity (Fig. 2a). Based on this sampling for 2008, the annual average DOC concentration is $1.9 \mathrm{mg} / \mathrm{L}$ with a standard deviation of $1.0 \mathrm{mg} / \mathrm{L}$ and the annual average DIC concentration is $3.0 \mathrm{mg} / \mathrm{L}$ with a standard deviation of $1.2 \mathrm{mg} / \mathrm{L}$. The median DOC concentration is $1.7 \mathrm{mg} / \mathrm{L}$ and the median DIC concentration is $2.8 \mathrm{mg} / \mathrm{L}$. Using the observed stream flow for 2008 (Fig. 5), the flow-weighted DOC concentration is $2.0 \mathrm{mg} / \mathrm{L}$ with a standard deviation of $0.2 \mathrm{mg} / \mathrm{L}$ and the flow weighted DIC concentration is $2.8 \mathrm{mg} / \mathrm{L}$ with a standard deviation of $0.3 \mathrm{mg} / \mathrm{L}$. The median flow-weighted DOC concentration is $1.6 \mathrm{mg} / \mathrm{L}$ and the median flow-weighted DIC concentration is $2.4 \mathrm{mg} / \mathrm{L}$. The estimated carbon fluxes and release rates 


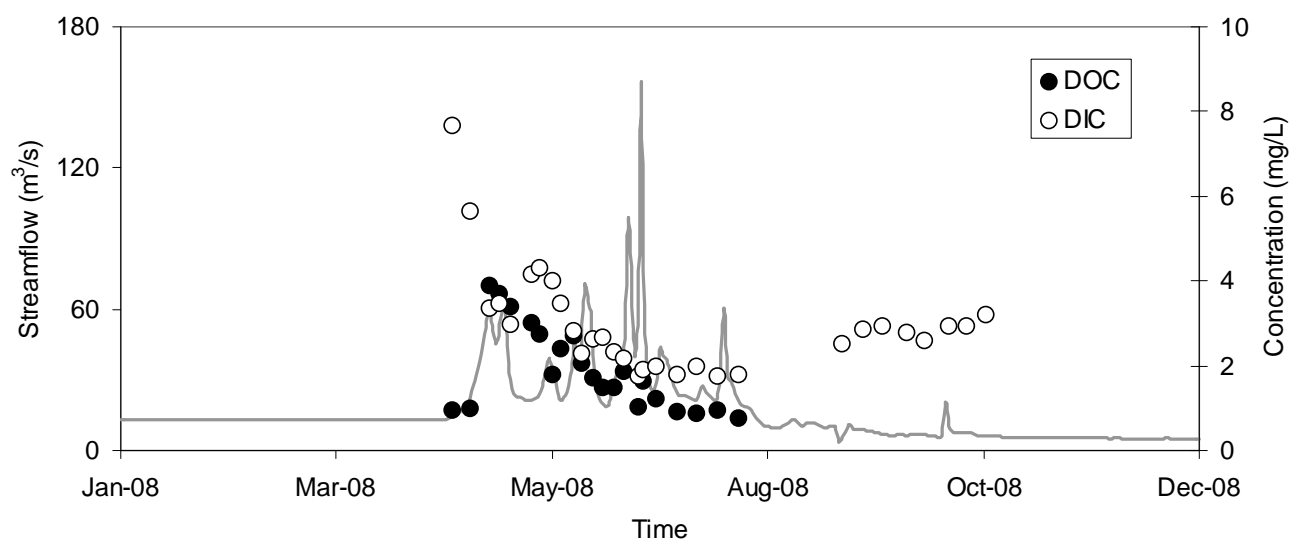

Fig. 5. Time series of observed concentrations of DOC (closed symbols) and DIC (open symbols) at the outlet of the Abiskojokken catchment along with observed hydrograph for 2008.

for the Abiskojokken catchment vary depending on assuming a spatially-distributed or catchment-averaged travel time (Table 1).

\section{Discussion}

\subsection{Estimation and validation of advective travel times}

This study uses a practical and easily applicable framework analogous to the flow modeling methodology outlined in Jarsjö et al. (2007) and the travel time-based mass transport methodology outlined in Darracq et al. (2009) for determining the spatial distribution of advective travel times. This approach is advantageous particularly in ungauged or data limited environments. Often, only topographic and minimal soil data are available at the catchment-scale. This makes the modeling of solute transport and reactive mass transfer/transformation difficult, not least with respect to creating a meaningfully representation of how solutes are physically transported through the catchment. By adopting a physical (advective) travel time-based methodology, we can clearly represent the interaction between physical and biogeochemical processes that affect solutes in their transport through the landscape in process-based transport models. As more information becomes available in data limited environments, such as Abiskojokken catchment, estimations of the spatial distributions of advective travel times that represent the physical solute transport can be more constrained.

We have here assumed that Darcy's law is locally applicable to describe the flux of water along single flow and transport pathways (stream tubes). In addition, we have assumed that, in the absence of observed hydraulic gradients, the surface topography gradient can be used to approximate the water table gradient. These estimated advective travel times (Fig. 3) vary among the different land surface locations over the whole catchment. The influence of using a hillslopeaverage hydraulic gradient can be seen in the relative travel time uniformity across hillslopes. This is compared to the greater travel time variability when moving along hillslopes, from flow divides to the stream channel. Shorter travel times result nearer to the stream network due to the decreased flow pathway length. Moreover, owing to limited data availability and resolution, we have assumed that hydraulic parameters are spatially homogeneous over the entire extent of the Abiskojokken catchment. This, however, is not a necessary condition. If detailed mapping of for instance hydraulic conductivity and its variability were available across the catchment, this type of information could and should be used in the estimation of the advective travel time distribution. In addition to hydraulic properties, the value adopted for $\alpha_{\mathrm{sh}}$ is a key parameter for the estimation of the spatially distributed travel times. As such, its value needs to be constrained based on independent hydrologic measurements and theory. Here, it was possible to constrain this $\alpha_{\text {sh }}$ value based on independent hydrologic measurements and theory using alkalinity as a long-term tracer of water originating from the deep reservoir (Fig. 2). Other methods may be available to estimate this weighting parameter for water flow fractionation between shallow and deep aquifers (e.g., Eriksson and Destouni, 1997).

Confidence is given to the modeled distribution by independent corroboration with field-based aquifer thickness observations and by comparison with previous empirical estimates of catchment-scale travel time made in this region. In the current study, the estimated aquifer thickness of $8 \mathrm{~m}$ for the whole subsurface flow domain, which is based entirely on observed and modeled hydrology, agrees well with observed aquifer depths in quaternary deposits ranging from $1.7 \mathrm{~m}$ to $5.3 \mathrm{~m}$ in a nearby $(<100 \mathrm{~km})$ headwaters of river Kalixälven (Smedberg et al., 2006) and regionally-based median values for herbaceous and mixed forest land covers of $7 \mathrm{~m}$ and $9 \mathrm{~m}$, respectively (Smedberg et al., 2009). As such, we can accept the hydrological characterizations assumed for both the shallow and deeper flow domains in generating the 
Table 1. Observed concentrations (in italics) and estimated carbon fluxes and release rates for the Abiskojokken catchment. In parenthesis, are standard deviations for observed concentrations and corresponding standard errors (based on one standard deviation) for estimated values.

\begin{tabular}{|c|c|c|c|}
\hline Measure & Parameter & Units & Values \\
\hline Flux-averaged DOC concentration in the stream & $\overline{C_{\text {DOC-flux }}}$ & $m g C m^{-3}$ & $2000(200)$ \\
\hline Average DOC mass flux into the stream & $\overline{s_{\mathrm{DOC}}}$ & $\mathrm{mgC} \mathrm{m}{ }^{-2} \mathrm{~s}^{-1}$ & $571(57)$ \\
\hline $\begin{array}{l}\text { Homogeneous DOC mass flux, based on the above release rate with a } \\
\text { lumped, single travel time and flow velocity }\end{array}$ & $\overline{s_{\mathrm{DOC}}}(\bar{\tau})$ & $\mathrm{mg} \mathrm{C} \mathrm{m}{ }^{-2} \mathrm{~s}^{-1}$ & $726(72)$ \\
\hline DOC release rate based on spatially distributed travel time & $r_{\mathrm{DOC}}$ & $\mathrm{mg} \mathrm{C} \mathrm{m}{ }^{-3} \mathrm{~s}^{-1}$ & $0.36(0.04)$ \\
\hline $\begin{array}{l}\text { DOC release rate calculated from observed average mass flux with a } \\
\text { lumped, single travel time }\end{array}$ & $r_{\mathrm{DOC}}(\bar{\tau})$ & $\mathrm{mg} \mathrm{C} \mathrm{m}{ }^{-3} \mathrm{~s}^{-1}$ & $0.29(0.03)$ \\
\hline Flux-averaged DIC concentration in the stream & $\overline{C_{\text {DIC-flux }}}$ & $m g C m^{-3}$ & $2800(300)$ \\
\hline Average DIC mass flux into the stream & $\overline{s_{\text {DIC }}}$ & $\mathrm{mg} \mathrm{C} \mathrm{m}{ }^{-2} \mathrm{~s}^{-1}$ & $799(86)$ \\
\hline $\begin{array}{l}\text { Homogeneous DIC mass flux, based on the above release rate with a } \\
\text { lumped, single travel time and flow velocity }\end{array}$ & $\overline{s_{\mathrm{DIC}}}(\bar{\tau})$ & $\mathrm{mg} \mathrm{C} \mathrm{m}{ }^{-2} \mathrm{~s}^{-1}$ & $1016(109)$ \\
\hline DIC release rate based on spatially-distributed travel time & $r_{\text {DIC }}$ & $\mathrm{mg} \mathrm{C} \mathrm{m}{ }^{-3} \mathrm{~s}^{-1}$ & $0.51(0.05)$ \\
\hline $\begin{array}{l}\text { DIC release rate calculated from observed average mass flux with a } \\
\text { lumped, single travel time }\end{array}$ & $r_{\text {DIC }}(\bar{\tau})$ & $\mathrm{mg} \mathrm{C} \mathrm{m}{ }^{-3} \mathrm{~s}^{-1}$ & $0.40(0.04)$ \\
\hline
\end{tabular}

advective solute travel time distribution (Fig. 3). Further, the mean advective travel time modeled for the Abiskojokken catchment (0.9 years) is in general agreement with the 1.1 years estimated using 10 years of ${ }^{18} \mathrm{O}$ isotope signatures for the nearby $6000 \mathrm{~km}^{2}$ Torne älv catchment (Burgman et al., 1987). The slightly larger Torne älv catchment is subjected to a similar climate and has a similar geological setting as the Abiskojokken catchment.

\subsection{Carbon flux in relation to flow pathways}

For the Abiskojokken catchment, the fluxes of DOC and DIC from the subsurface landscape to the surface water system were comparable in magnitude (Table 1). DIC constitutes about $58 \%$ and DOC about $42 \%$ of the total flux of dissolved carbon through the landscape and into the stream network. This differs from the larger flux of DOC observed in many other northern landscapes. Looking over the whole of Sweden, Humborg et al. (2010) estimated that organic carbon comprised the majority of the carbon flux from the terrestrial environment to the aquatic system. For example, boreal landscapes tend to have a direct connection with wetlands rich in organic matter and large amounts of DOC in stream systems (Kortelainen, 1993; Laudon et al., 2004). For example, in the well studied Krycklan catchments (located about $600 \mathrm{~km}$ southeast of the Abiskojokken catchment), DOC comprises about $81 \%$ of the total dissolved carbon export while DIC makes up 19\% (Wallin et al., 2010). However, in contrast to the Swedish rivers where DOC concentrations are higher than DIC concentrations, most large Siberian rivers are richer in DIC than DOC. On average, DIC comprises $56 \%$ of the total dissolved carbon export (Gordeev et al., 1996), which is very similar to the Abiskojokken watershed. These various estimates, along with the present results, demonstrate the fundamental differences that arise due to variation in both ecosystem processes and subsurface materials with respect to the carbon transport through and from the subsurface landscape into the surface water system. As such, there is a need to represent an appropriate level of interaction between the terrestrial environment and hydrology in models to capture the real nature of carbon transport along and among the aquatic conduits (Cole et al., 2007).

In the current study, this can be seen by the comparisons of release rates based on spatially-distributed travel times with those estimated from a single, lumped travel time (Table 1). Lumping to create a mean travel time value led to underestimation of the release rates of both DIC and DOC (Table 1). For the present-day Abiskojokken catchment, the local DIC release rate was underestimated by $22 \%$ and the local DOC release rate by $19 \%$. The differences found here between DIC and DOC release rates (and mass fluxes) when considering spatially distributed travel times over a single lumped travel time are similar to previous findings considering other types of, or more general, solute transport (e.g., Eriksson and Destouni, 1997; Malmström et al., 2000; Lindgren and Destouni, 2004). Such differences in how we represent the movement of water through the catchment subsurface will greatly affect interpretations and predictions of the $\mathrm{CO}_{2}$ sink or source functioning of the landscape within hydrological catchments. The first approximation given in this study elucidates the role of hydrological flow and transport and the 
need for more process-based studies that consider this role and its possible climate feedbacks. This role may be even more important under future climate conditions, when the balance between DOC and DIC in taiga and tundra catchments (such as Abiskojokken) may be become even more sensitive to the hydrologic regimes.

\subsection{On the potential effects of changes to flow pathways in the sub-arctic}

Localized (Åkerman and Johansson, 2008) and catchmentscale (Lyon et al., 2009) permafrost thawing has been documented in Abiskojokken. This thawing has already led to changes in the storage-discharge dynamics of the catchment (Lyon et al., 2009) and could also influence future shifts in the hydrologic flow pathways at the catchment scale. The flow in deeper pathways, for example, has the potential to be slower as hydraulic conductivity in Swedish soil-rock systems typically decreases with depth into the subsurface profile. This will likely change the advective travel times through the catchment. Such changes could be represented in the current modeling conceptualization by allowing deeper subsurface flow pathways to shift the advective travel time distribution from the present-day distribution towards a distribution that includes the longer travel times associated with the deeper and slower flow. In addition, physically-based models (e.g., Grimm and Painter, 2009) could allow for more explicit accounting of changes in flow pathways and associated advective travel times due to permafrost thawing.

Fluvial and ground water exports of dissolved carbon may be affected by such climate change-induced (or land-use induced) changes in hydrology (Cole et al., 2007). Evidence for this has been found for the Yukon River Basin where decreasing DOC concentrations during summer has been explained by increased flow path and travel times in combination with increased microbial mineralization of DOC in the soil active layer and groundwater (Striegl et al., 2007). A general increasing trend in the groundwater contribution has also been observed across the Yukon River Basin as a result of changed hydrological flow paths due to permafrost thawing and this alteration of flow paths is believed to further decrease DOC exports and increase DIC exports (Walvoord and Striegl, 2007; Lyon and Destouni, 2010). Accordingly, Hinzman et al. (2005) observed increasing DIC concentrations (together with $\mathrm{Mg}, \mathrm{Ca}$ and $\mathrm{K}$ ) in Toolik Lake, Alaska, suggesting deeper infiltration of runoff water and increased weathering. For systems where the exports of DOC and DIC are currently in a relative balance (such as the Abiskojokken catchment), such large-scale changes in flow pathways could ultimately shift this balance.
Acknowledgements. The authors acknowledge funding from the Swedish Research Council (VR) and the Bert Bolin Centre for Climate Research, which is supported by a Linnaeus grant from VR and The Swedish Research Council Formas.

Edited by: E. Zehe

\section{References}

Åkerman, H. J. and Johansson, M.: Thawing permafrost and thicker active layers in sub-arctic Sweden, Permafrost and Periglacial Proc., 19(3), 279-292, 2008.

Åkerman, H. J. and Malmström, B.: Permafrost mounds in the Abisko area, northern Sweden, Geografiska Annaler, A68(3), 155-165, 1986.

Bogaart, P. W. and Troch, P. A.: Curvature distribution within hillslopes and catchments and its effect on the hydrological response, Hydrol. Earth Syst. Sci., 10, 925-936, doi:10.5194/hess10-925-2006, 2006.

Bring, A. and Destouni, G.: Hydrological and hydrochemical observation status in the Pan-Arctic drainage basin, Polar Research, 28, 3, doi:10.1111/j.1751-8369.2009.00126.x, 2009.

Brown, R. D. and Braaten, R. O.: Spatial and temporal variability of Canadian monthly snow depth, 1946-1995, Atmos. Ocean, 36, 37-54, 1998.

Buttle, J. and McDonnell, J. J.: Isotope tracers in catchment hydrology in the humid tropics, in: Forest-Water-People in the Humid Tropics, edited by: Bonell, M. and Bruijnzeel, L. A., Cambridge University Press, New York, 770-789, 2004.

Burgman, J. O., Calles, B., and Westman, F.: Conclusions from a ten year study of oxygen-8 in precipitation and runoff in Sweden, in: Isotope techniques in water resources development. IAEA Division of Publications, ISBN 92-0-040087-6, 815 pp., 1987.

Cole, J. J., Prairie, Y. T., Caraco, N. F., McDowell, W. H., Tranvik, L. J., Striegl, R. G., Duarte, C. M., Kortelainen, P., Downing, J. A., Middelburg, J. J., and Melack, J.: Plumbing the global carbon cycle: Integrating inland waters into the terrestrial carbon budget, Ecosystems, 10, 171-184, 2007.

Curtis, J., Wendler, G., Stone, R., and Dutton, E.: Precipitation decrease in the western Arctic, with special emphasis on Barrow and Barter Island, Alaska, Int. J. Climatol., 18, 1687-1707, 1998.

Darracq, A., Destouni, G., Persson, K., Prieto, C., and Jarsjö, J.: Quantification of advective solute travel times and mass transport through hydrological catchments, Environ. Fluid Mech., 10, 1-2, doi:10.1007/s10652-009-9147-2, 2009.

Destouni, G. and Graham, W. D.: Solute transport through an integrated heterogeneous soil-groundwater system, Water Resour. Res., 31, 1935-1944, 1995.

Destouni, G., Shibuo, Y., and Jarsjö, J.: Freshwater flows to the sea: Spatial variability, statistics and scale dependence along coastlines, Geophys. Res. Lett., 35, L18401, doi:10.1029/2008GL035064, 2008a.

Destouni, G., Hannerz, F., Prieto, C., Jarsjö, J., and Shibuo, Y.: Small unmonitored near-coastal catchment areas yielding large mass loading to the sea, Global Biogeochem. Cycles, 22, GB4003, doi:10.1029/2008GB003287, 2008b.

Déry, S. J., Stieglitz, M., McKenna, E. C., and Wood, E. F.: Characteristics and trends of river discharge into Hudson, James, and Ungava Bays, 1964-2000, J. Climate, 18, 2540-2557, 2005. 
Dutta, K., Schuur, E. A. G., Neff, J. C., and Zimov, S. A.: Potential carbon release from permafrost soils of Northeastern Siberia, Global Change Biol., 12, 2336-2351, 2006.

Eriksson, N. and Destouni, G.: Combined effects of dissolution kinetics, secondary mineral precipitation, and preferential flow on copper leaching from mineral waste rock, Water Resour. Res., 33(3), 471-483, 1997.

Frey, K. E. and McClelland, J. W.: Impacts of permafrost degradation on arctic river biogeochemistry, Hydrol. Processes, 23, 169-182, 2009.

Gordeev, V. V., Martin, J. M., Sidorov, I. S., and Sidorova, M. V.: A reassessment of the Eurasian river input of water, sediment, major elements, and nutrients to the Arctic Ocean, American J. Sci., 296, 664-691, 1996.

Grimm, R. E. and Painter, S .L.: On the secular evolution of groundwater on Mars, Geophys. Res. Lett., 36, L24803, doi:10.1029/2009GL041018, 2009.

Hannerz, F. and Destouni, G.: Spatial characterization of the Baltic Sea drainage basin and its unmonitored catchments, Ambio, 35(5), 214-219, 2006.

Hinzman, L. D., Bettez, N. D., Bolton, W. R., et al.: Evidence and implications of recent climate change in northern Alaska and other arctic regions, Climatic Change, 72, 251-298, 2005.

Humborg, C., Smedberg, E., Blomqvist, S., Morth, C.M., Brink, J., Rahm, L., Danielsson, A., and Sahlberg, J.: Nutrient variations in boreal and subarctic Swedish rivers: Landscape control of landsea fluxes, Limnol. Oceanogr., 49, 1871-1883, 2004.

Humborg, C., Mörth, C., Sundbom, M., Borg, H., Blenckner, T., Giesler, R., and Ittekkot, V.: $\mathrm{CO}_{2}$ supersaturation along the aquatic conduit in Swedish watersheds as constrained by terrestrial respiration, aquatic respiration and weathering, Global Change Biol., 16, 7, doi:10.1111/j.1365-2486.2009.02092.x, 2010.

Jarsjö, J., Destouni, G., Persson, K., and Prieto, C.: Solute transport in coupled inland-coastal water systems: General conceptualization and application to Forsmark, Swedish Nuclear Fuel and Waste Management Co Report R-07-65, Stockholm, 2007.

Johansson, M., Christensen, T. R., Åkerman, H. J., and Callaghan, T. V.: What determines the current presence or absence of permafrost in the Torneträsk region, a sub-arctic landscape in northern Sweden?, Ambio, 35(4), 190-197, 2006.

Johansson, P.-O., Werner, K., Bosson, E., and Juston, J.: Description of climate, surface hydrology, and near-surface hydrology. Preliminary site description. Forsmark area - version 1.2.; Swedish Nuclear Waste Management Company (SKB) Report R-05-06, Stockholm, 2005.

Kane, D. L., Bredthauer, S. R., and Stein, J.: Subarctic snowmelt runoff generation, in: Proceedings of the Specialty Conference on The Northern Community, edited by: Vinson, T. S., American Society of Civil Engineers, Seattle, Washington, 591-601, 1981.

Kirchner, J. W., Feng, X., and Neal, C.: Catchment-scale advection and dispersion as a mechanism for fractal scaling in stream tracer concentrations, J. Hydrol., 254, 82-101, 2001.

Kortelainen, P.: Content of total organic-carbon in Finnish lakes and its relationship to catchment characteristics, Can. J. Fish. Aquat. Sci., 50, 1477-1483, 1993.

Laudon, H., Köhler, S., and Buffam, I.: Seasonal dependency in DOC export from seven boreal catchments in northern Sweden, Aquat. Sci., 66, 223-230, 2004.
Lindgren, G. and Destouni, G.: Nitrogen loss rates in streams: scale-dependence and up-scaling methodology, Geophys. Res. Lett., 31, L13501, doi:10.1029/2004GL019996, 2004.

Lindgren, G. A., Destouni, G., and Miller, A. V.: Solute transport through the integrated groundwater-stream system of a catchment, Water Resour. Res., 40, W03511, doi:10.1029/2003WR002765, 2004.

Lyon, S. W., Destouni, G., Giesler, R., Humborg, C., Mörth, M., Seibert, J., Karlsson, J., and Troch, P. A.: Estimation of permafrost thawing rates in a sub-arctic catchment using recession flow analysis, Hydrol. Earth Syst. Sci., 13, 595-604, doi:10.5194/hess-13-595-2009, 2009.

Lyon, S. W. and Destouni, G.: Changes in catchment-scale recession flow properties in response to permafrost thawing in the Yukon River Basin, Int. J. Climatol., in press, 2010.

MacLean, R. M., Oswood, M. W., Irons III, J. G., and McDowell, W. H.: The effect of permafrost on stream biogeochemistry: a case study of two streams in the Alaskan (USA) taiga, Biogeochemistry, 47, 239-267, 1999.

Malmström, M., Destouni, G., Banwart, S., and Strömberg, B.: Resolving the scale-dependence of mineral weathering rates, Environ. Sci. Technol., 34, 1375-1378, 2000.

Malmström, M., Destouni, G., and Martinet, P.: Modeling expected solute concentration in randomly heterogeneous flow systems with multi-component reactions, Environ. Sci. Technol., 38, 2673-2679, 2004.

McCabe, G. J., Clark, M. P., and Serreze, M. C.: Trends in Northern Hemisphere surface cyclone frequency and intensity, J. Climate, 14, 2763-2768, 2001.

McNamara, J. P., Kane, D. L., Hobbie, J., and Kling, G. W.: Hydrologic and biogeochemical controls on the spatial and temporal patterns of nitrogen and phosphorus in an Arctic river, Hydrol. Processes, 17, 3294-3309, 2008.

Osterkamp, T. E.: Characteristics of the recent warming of permafrost in Alaska, J. Geophys. Res., 112, F02S02, doi:10.1029/2006JF000578, 2007.

Parkhurst, D. L. and Appelo, C. A. J.: User's guide to PHREEQC (version 2) - A computer program for speciation, batch-reaction, one-dimensional transport, and inverse geochemical calculations, U.S.G.S Water-Resources Investigations Report 99-4259, 312 pp., 1999.

Persson, K. and Destouni, G.: Propagation of water pollution uncertainty and risk from the subsurface to the surface water system of a catchment, J. Hydrol., 377, 434-444, doi:10.1016/j.hydrol.2009.09.001, 2009.

Peterson, B. J., Holmes, R. M., McClelland, J. W., Vörösmarty, C. J., Lammers, R. B., Shiklomanov, A. I., Shiklomanov, I. A., and Rahmstor, S.: Increasing river discharge to the Arctic Ocean, Science, 298, 2171-2173, 2002.

Simic, E. and Destouni, G.: Water and solute residence times in a catchment: Stochastic model interpretation of 180 transport, Water Resour. Res., 35, 2109-2119, 1999.

Sklash, M. G. and Farvolden, R. N.: The role of groundwater in storm runoff, J. Hydrol., 43, 45-65, 1979.

Smedberg, E., Mörth, C.-M., Swaney, D. P., and Humborg, C.: Modelling hydrology and silicon-carbon interactions in taiga and tundra biomes from a landscape perspective: Implications for global warming feedbacks, Global Biogeochem. Cycles, 20, GB2014, doi:10.1029/2005GB002567, 2006. 
Smedberg, E., Humborg, C., Jakobsson, M., and Mörth, C.-M.: Landscape elements and river chemistry as affected by river regulation - a 3-D perspective, Hydrol. Earth Syst. Sci., 13, 15971606, doi:10.5194/hess-13-1597-2009, 2009.

Sobek, S., Algesten, G., Bergstrom, A. K., Jansson, M., and Tranvik, L. J.: The catchment and climate regulation of $\mathrm{pCO}(2)$ in boreal lakes, Global Change Biology, 9, 630-641, 2003.

Stieglitz, M., Déry, S. J., Romanovsky, V. E., and Osterkamp, T. E.: The role of snow cover in the warming of Arctic permafrost, Geophys. Res. Lett., 30(13), 1721, doi:10.1029/2003GL017337, 2003.

Striegl, R. G., Aiken, G. R., Dornblaser, M. M., Raymond, P. A., and Wickland, K. P.: A decrease in discharge-normalized DOC export by the Yukon River during summer through autumn, Geophys. Res. Lett., 32, L21413, doi:10.1029/2005GL024413, 2005.

Tarboton, D. G.: A New Method for the Determination of Flow Directions and Contributing Areas in Grid Digital Elevation Models, Water Resour. Res., 33(2), 309-319, 1997.
Wallin, M., Buffam, I., Öquist, M., Laudon, H., and Bishop, K.: Temporal and spatial variability of dissolved inorganic carbon in a boreal stream network - concentrations and downstream fluxes, J. Geophys. Res.-Biogeosci., 115, G02014, doi:10.1029/2009JG001100, 2010.

Walsh, J. E.: Global atmospheric circulation patterns and relationships to Arctic freshwater fluxes, in: The Freshwater Budget of the Arctic Ocean, edited by: Lewis, E. L., Jones, E. P., Lemke, P., et al., NATO Science Series 2: Environmental Security, vol. 7, Kluwer Academic, 21-43, 2000.

Walvoord, M. A. and Striegl, R. G.: Increased groundwater to stream discharge from permafrost thawing in the Yukon River basin: Potential impacts on lateral export of carbon and nitrogen, Geophys. Res. Lett., 34, L12402, doi:10.1029/2007GL030216, 2007.

White, D., Hinzman, L. D., Alessa, L., et al.: The arctic freshwater system: changes and impacts, J. Geophys. Res., 112, G04S54, doi:10.1029/2006JG000353, 2007.

Woo, M. K., Kane, D. L., Carey, S. K., and Yang, D.: Progress in permafrost hydrology in the new millennium, Permafrost and Periglacial Processes, 19, 237-254, 2008. 